\title{
RANCANG BANGUN ALGORITMA DAN APLIKASINYA PADA AKUSTIK SINGLE BEAM UNTUK PENDETEKSIAN BAWAH AIR
}

\section{(DESIGN OF ALGORITHMS AND IT'S APPLICATION TO SINGLEBEAM ACOUSTIC FOR UNDERWATER DETECTION)}

\author{
Asep Ma'mun',2, Henry M. Manik' ${ }^{2}$, Totok Hestirianoto ${ }^{2}$ \\ ${ }^{1}$ Corresponding author \\ 2Departemen Ilmu dan Teknologi Kelautan \\ Fakultas Perikanan dan Ilmu Kelautan, Institut Pertanian Bogor \\ E-mail: asepmamun@gmail.com
}

\begin{abstract}
Application of acoustic technology for underwater detection can be differentiated into four types, namely singlebeam, dualbeam, splitbeam and multibeam. The more acoustic beam constructed within the instrument, more expensive it gets and the higher details of detection and accuracy resulted. Thus, singlebeam acoustic remain as the most widely applied acoustics particularly in developing country. The presence of Cruapro Fishfinder, as alternative multibeam. Acoustic instrument provide promixing as well as unfavoring consequences. Its capacity for internal data storage becomes handy, while unavailability for raw data signal processing requires important breakthrough. This study is developing algorithm for acoustic signal processing embedded in Matlab package. From this study obtain good accuracy and precisionmeasurement to sphere ball. Several functions were applied, beam width, absorption coefficient and sound velocity; during development and sphere detection. Algorithm developed was proven efficient and useful for raw data processing of Cruzpro singlebeam acoustic, as revealed by low standard deviation of 0,13 with $95 \%$ confidence interval.
\end{abstract}

Keywords: Algorithms, accuracy, precision, signal processing, single beam, Cruzpro

\begin{abstract}
ABSTRAK
Aplikasi teknologi akustik untuk deteksi bawah laut dapat dibedakan menjadi empat tipe, yaitu singlebeam, dualbeam, splitbeam, dan multibeam. Semakin banyak beam yang digunakan pada instrumen, maka semakin mahal harganya dan detail serta akurasi yang didapat semakin tinggi. Meskipun demikian, singlebeam merupakan alat yang lebih banyak digunakan di negara berkembang. Kehadiran Cruzpro fishfinder digunakan sebagai alternatif pemakaian multibeam. Kedua instrumen akustik tersebut dapat memberikan hasil yang hampir sama baiknya. Penyimpanan data internal Cruzpro fishfinder cenderung mudah dilakukan, tetapi ketiadaan untuk pengolahan data mentah ini menjadi hal penting untuk selanjutnya dikembangkan. Penelitian ini mengembangkan algoritma untuk pengolahan sinyal akustik yang dibuat dalam bentuk package Matlab. Didapatkan akurasi dan presisi yang baik dari pengukuran terhadap bola sphere. Beberapa rumusan seperti beam width, koefisien absorbsi, dan kecepatan suara, digunakan selama pengembangan dan dalam pendeteksian bola sphere. Pengembangan algoritma ini telah terbukti efisien dan berguna untuk pengolahan data mentah singlebeam Cruzpro, dengan standar deviasi 0,13 dengan selang kepercayaan 95\%.
\end{abstract}

Kata kunci: Algoritma, akurasi, presisi, pemerosesan signal, singelbeam, Cruzpro

\section{PENDAHULUAN}

Teknologi akustik merupakan teknologi yang banyak diandalkan dalam pendekteksian bawah air seperti stok sumberdaya organisme, klasifikasi dasar perairan, migrasi organisme, pengkajian struktur bangunan, monitoring pipa bawah laut dan estimasi kandungan mineral. Teknologi ini pada dasarnya memanfaatkan nilai hambur balik suara yang dipancarkan. Dalam penginterpretasian data akustik meliputi beberapa tahapan yaitu proses pembentukan suara, pelepasan suara, pemantulan oleh objek, penangkapan sinyal kembali dan penginterpretasian data. Pemerosesan sinyal yang kembali merupakan salah satu bagian yang penting dari penginterpretasian data, karena pada tahapan ini akan menentukan kualitas data yang diharapkan dapat menggambarkan objek atau lingkungan disekitarnya. Kalibrasi merupakan faktor yang perlu dilakukan pada setiap pemerosesan data karena dalam proses perjalananya akan dipengaruhi oleh beberapa faktor dari ling- 
kungan ataupun dari komponen alat itu sendiri (Mac-Lennan, 2005).

Lurton (2002) menyatakan bahwa instrumen akustik dapat dibedakan menjadi 4 jenis yaitu singelbeam, dualbeam, splitbeam dan multibeam. Banyaknya beam pada instrumen tersebut yang membedakan satu dan lainnya. Semakin banyak beam yang digunakan pada alat, umumnya akan memberikan hasil yang baik untuk penginterpretasian data. Alat yang termasuk jenis tersebut adalah splitbeam dan multibeam. Alat jenis ini merupakan teknologi yang cukup mahal, sehingga pada saat ini hanya mampu dimiliki beberapa instansi.

Fishfinder merupakan alat akustik yang relatif jauh lebih murah dan mudah dijangkau. CruzPro fishfinder merupakan salah satu contoh jenis alat akustik tersebut. CruzPro fishfinder memiliki kemampuan untuk menyimpan data, namun tidak diiringi dengan perkembangan teknologi pengolahan data yang dihasilkan. Data hasil akusisi CruzPro fishfinder disimpan dalam jenis data ASCII (American Standard Code for Information Interchange). Data ini dapat diakses oleh bahasa pemrograman $\mathrm{C}++$.

Tujuan dari penelitian yaitu menciptakan algoritma untuk pengkuantifikasian data hidroakustik seperti Target strength dan Scattering volume dari data singelbeam, dimana nilai-nilai ini sangat penting untuk pengkajian secara hidroakustik. Menguji akurasi dan presisi algoritma yang telah diciptakan, sehingga alat ini dapat dikatakan layak digunakan untuk aplikasi lainya. Menciptakan pengolahan data singlebeam berbasis package Matlab yang user friendly.

\section{METODE PENELITIAN}

Pengambilan data dilakukan di watertank, Bagian Akustik dan Instrumentasi Kelautan, Departemen Ilmu dan Teknologi Kelautan, FPIK-IPB, dengan menggunakan singelbeam CruzPro fishfinder pada tanggal 20 Februari 2013, dan dilanjutkan dengan pembentukan algoritma, uji coba dan pembentukan . Nilai acuan yaitu bola sphere $200 \mathrm{KHz}(\mathrm{d}=36 \mathrm{~mm}$, TS $=-39,9 \mathrm{~dB}$, dengan $\mathrm{C}=1500 \mathrm{~m} / \mathrm{s}$ dan durasi pulsa $0,5 \mathrm{~ms})$. Penelitian ini diawali dengan menganalisis masalah, pengumpulan data dan pemisahan data, pembuatan algoritma, pengujian algoritma, dan pembuatan program (Gambar 1). Beberapa asumsi yang berlaku dalam pembentukan algoritma yaitu; penyimpangan nilai atau error pengukuran akibat faktor lainya yang tidak diperhitungkan dalam pembentukan algoritma (bersifat independen), hasil dari kuantifikasi algoritma jika dibandingkan dengan nilai kontrol dengan menggunakan uji akurasi dan presisi diperoleh hasil yang baik, maka algoritma ini dapat digunakan dan dicari turunan algoritmanya.

Beberapa hipotesis yang akan diuji pada penelitian ini antara lain:

1. Uji Akurasi dan Uji Presisi

Soeta'at pada tahun 1996 menyatakan bahwa akurasi dinyatakan baik jika jumlah total selisih kuadrat hasil suatu pengukuran dengan kontrol lebih kecil atau sama dengan tiga kali jumlah total kuadrat kontrol. Nilai kontrol untuk uji akurasi dan presisi pada penelitian ini adalah menggunakan bola sphere yang bernilai $-39,9$ dB. Akurasi dinyatakan kurang, jika jumlah total selisih kuadrat hasil pengukuran dengan kontrol lebih besar dari tiga kali jumlah total kuadrat kontrol.

Sedangkan, presisi baik dinyatakan jika jumlah total kuadrat hasil pengukuran lebih kecil atau sama dengan dua kali jumlah total kuadrat kontrol. Sedangkan, presisi dikatakan kurang jika jumlah total kuadrat hasil pengukuran lebih besar dari dua kali jumlah total kuadrat kontrol (bola sphere).

2. Uji Homogenitas (Uji Fisher)

Dalam Supardi (2011) untuk pengujian tingkat kesamaan data menggunakan hipotesis sebagai berikut, $\mathrm{H}_{0}$ : Nilai varian dari kelompok data hasil pengukuran sama dengan nilai varian dari kelompok data kontrol atau data pembanding (instrumen lain). Dapat dikatakan nilai yang dihasilkan homogen. $\mathrm{H}_{1}$ : Nilai varian dari kelompok data hasil pengukuran tidak sama dengan nilai varian dari kelompok data kontrol atau data pembanding (instrumen lain). Dapat dikatakan nilai yang dihasilkan tidak homogen. Sedangkan untuk kriteria pengujian hipotesis adalah sebagai berikut: Terima $\mathrm{H}_{0}$, jika $\mathrm{F}_{\text {hitung }}<\mathrm{F}_{\text {tabel }}$ dan Tolak $\mathrm{H}_{0}$, jika $\mathrm{F}_{\text {hitung }}>\mathrm{F}_{\text {tabel }}$. 


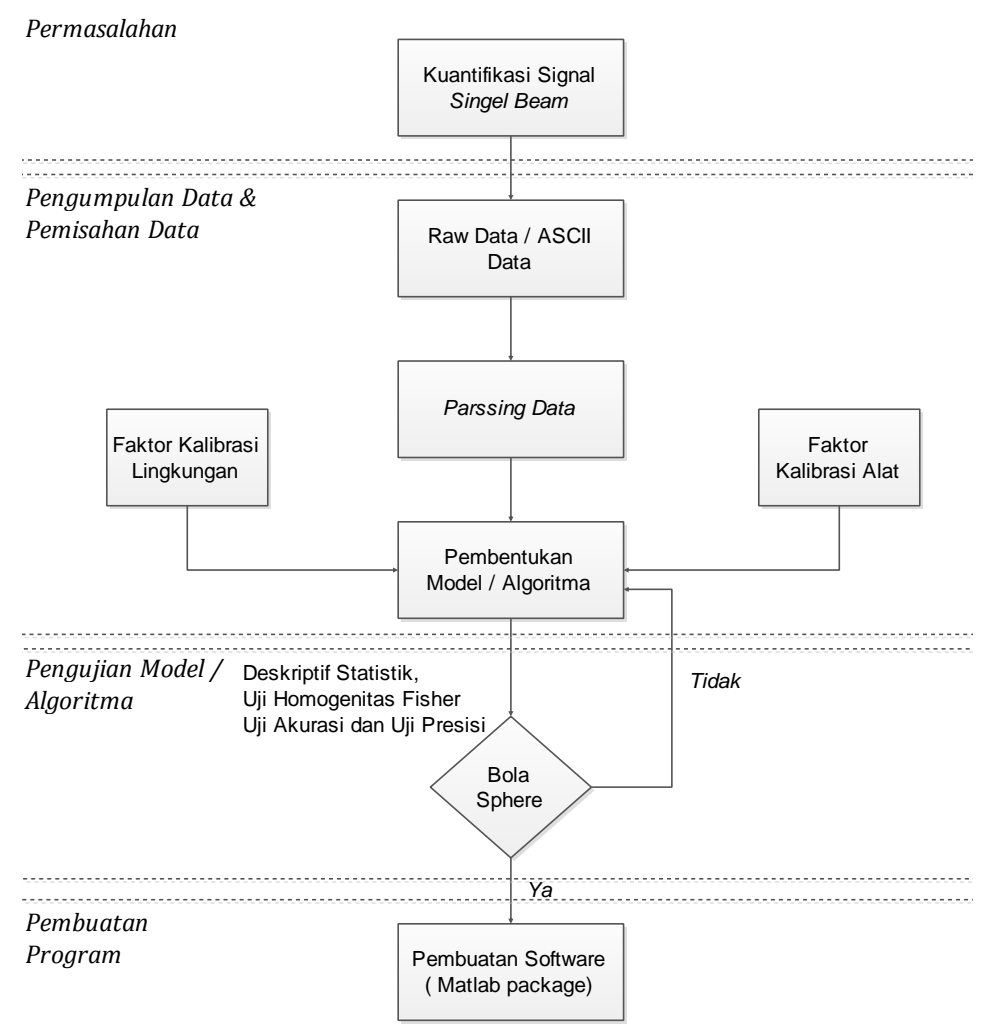

Gambar 1. Prosedur penelitian

\section{HASIL DAN PEMBAHASAN}

Nilai hambur balik suara merupakan logaritimik perbandingan antara besarnya intensitas yang dikembalikan berbanding dengan besarnya intensitas yang dipancarkan oleh alat tersebut. Besaran yang sering digunakan yaitu desibel (dB) (Lurton, 2002). Sinyal yang kembali umumnya memiliki nilai intensitas yang lemah sehingga dibutuhkan penguatan terhadap sinyal tersebut yang besarnya dengan menggunakan fungsi TVG (Time Varied Gain) untuk single target menggunakan fungsi $40 \log r$ dan untuk multiple target menggunakan fungsi $20 \log r$. Besarnya nilai echo dari suatu target untuk singelbeam dapat dinyatakan sebagai berikut:

$\mathrm{TS}=20 \log$ (counts) $-\mathrm{SL}+2 \mathrm{TL}-\mathrm{RS}+\mathrm{PS}$

+ TVG

dimana TS adalah nilai Target strength dari suatu target dan counts merupakan nilai intensitas yang diterima kembali oleh echosounder. SL merupakan source level atau intensitas suara yang dihasilkan oleh echosounder, dengan satuan $\mathrm{dB}$ re $1 \mu \mathrm{Pa}$ pada $1 \mathrm{~m}$. TL (transmition loss) banyaknya energi yang hilang akibat penyerapan dan perjalananya di kolom perairan. RS (receive sensitivity) faktor sensitifitas dari echosounder, sedangkan PS (Power Setting) merupakan kekuatan listrik yang digunakan kedua faktor ini dinyatakan dalam bentuk logaritmik. Data hasil akusisi Cruzpro fishfinder merupakan data yang berbentuk nilai analog dengan bentuk biner yaitu 8 bit. Untuk mengkonversi nilai tersebut kedalam bilangan digital number, maka setiap nilai yang dihasilkan dibagi dengan nilai maksimum dari 8 bit yaitu 256. Tanudjaja pada tahun 2007 menyatakan proses ini sering disebut dengan istilah ADC (Analog to Digital converter). Dalam hal ini Cruzpro fishfinder menginisialisasi nilai tersebut dari 0-255, secara sistematis dapat dituliskan sebagai berikut:

Count $=\frac{N A}{255}$......

Dimana, NA adalah nilai analog hasil akusisi Cruzpro fishfinder yang kemudian akan dinyatakan dalam bentuk logaritmik. Menurut Greenlaw et al pada tahun 2004 menyatakan bahwa penga- 
ruh pola beam yang dibentuk dari faktorfaktor tersebut perlu diperhitungkan.

$\mathrm{Ce}=10 \log (\mathrm{c} \tau \psi / 2)$

Dimana, c adalah kecepatan suara $(\mathrm{m} / \mathrm{s})$, $\tau$ merupakan durasi pulsa dengan satuan (s), sedangkan $\psi=$ equivalent twoway beam angle (steradian). Dari hasil serangkaian uji coba yang dilakukan diperoleh suatu tetapan yang dihasilkan sebagai faktor koreksi karena adanya perbedaan peruntukan penggunaan bola sphere (nilai kontrol) yang digunakan yaitu dalam hal jenis alat. Nilai dari faktor koreksi tersebut dapat ditentukan dengan persamaan :

corr $=10 \log (c \tau / 2)$

Hasil dari persamaan (4), merupakan suatu nilai yang mengambarkan kemampuan suatu alat untuk membedakan suatu objek dengan objek lain yang berdekatan. Dengan melihat faktorfaktor yang mempengaruhi nilai hambur balik suatu target disaat pemancaran, pemantulan atau dari instumen itu sendiri. Secara matematis dapat dibentuk algoritma yang dihasilkan untuk Cruzpro fishfinder adalah sebagai berikut dengan menggabungkan persamaan (1),(2),(3) dan (4):

$\mathrm{TS}=20 \log ($ count $)-\mathrm{SL}+2 \mathrm{TL}-\mathrm{RS}+\mathrm{PS}+$ $\mathrm{TVG}+\mathrm{Ce}+$ corr

Persamaan (5) kemudian digunakan sebagai dasar algoritma untuk perhitungan nilai hambur balik suatu volume perairan atau sering disebut dengan istilah Volume backscattering strength (Sv). Hasil logaritmik dari luasan area reverberasi yang besarnya dapat dihitung sebagai berikut (Desamparados et al, 2010):

$\mathrm{V}=10 \log \left(\pi(\mathrm{D} \tan (\Phi))^{2}\right)$

Dimana, $\pi$ tetapan bernilai 3.14 , D adalah kedalaman perairan dengan satuan (m) dan $\Phi$ merupakan nilai dari setengah lebar beam (degree), sehingga secara matematis dapat dituliskan persamaanya sebagai berikut :

$\mathrm{Sv}=20 \log ($ Count $)-\mathrm{SL}+2 \mathrm{TL}-\mathrm{RS}+\mathrm{PS}+$ $\mathrm{TVG}+\mathrm{Ce}+\mathrm{corr}+\mathrm{V} \ldots \ldots \ldots \ldots \ldots \ldots \ldots \ldots . .(7)$

Algoritma yang dihasilkan pada persamaan (5) dan (7) penting penggunaannya untuk suatu pengkajian yang memanfaatkan nilai hambur balik dari sinyal akustik. Karena pada dasarnya kedua hal tersebut yang digunakan untuk suatu pengkajian seperti kuantifikasi biomassa, migrasi organisme, karakteristik suatu organisme, pemetaan habitat dasar perairan dan lain-lain.

\subsection{Hasil Uji Algoritma}

Hasil kuantifikasi terhadap bola sphere sebagai uji validasi dan presisi algoritma yang telah diciptakan. Untuk spesifikasi bola sphere dan parameter alat yang digunakan ditunjukan oleh Gambar 2 (a) nilai dan parameter tersebut merupakan hasil pengukuran dari rangkaian kalibrasi untuk penen.tuan nilai hambur.balik. bola.sphøire yang dilakukan oleh pihak produsen. Umumnya dilakukan dalam kondisi terkontrol pada saat pengukuran, sehingga semua kondisi dapat terukur dengan baik (Biosonic, 2004).
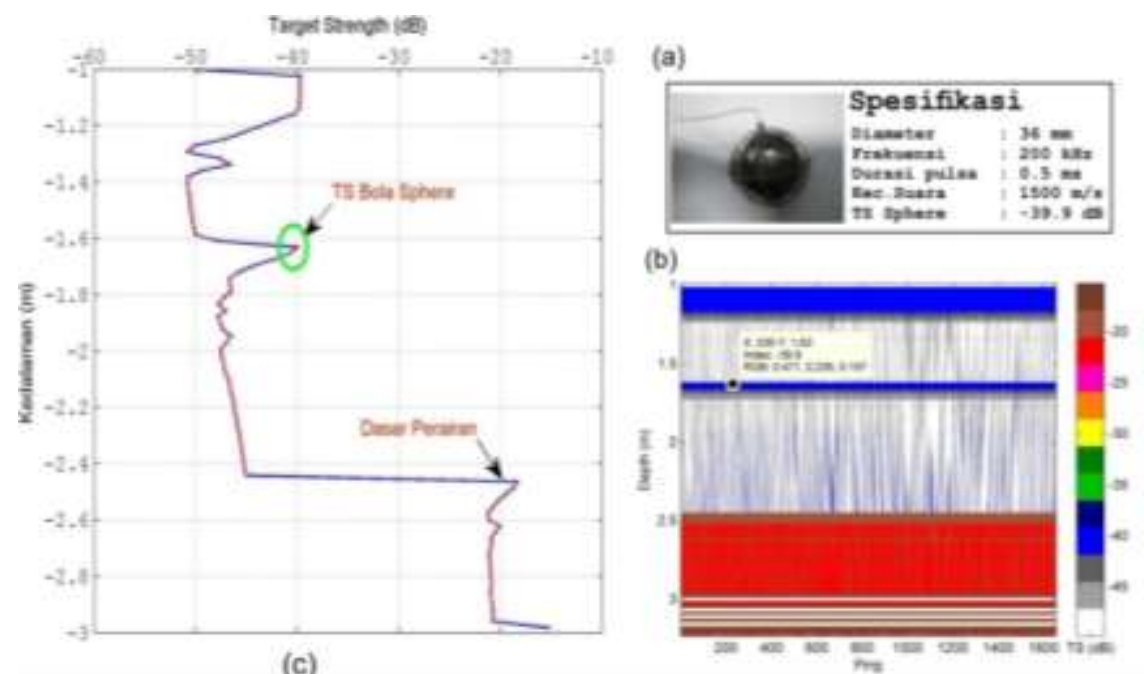

Gambar 2. (a) Spesifikasi bola sphere, (b) Visualisasi data hasil keluaran algoritma, (c) Gambar echo envelope nilai TS (dB) 
Pada gambar tersebut diperoleh gambaran dari permukaan air, kolom perairan, target bola sphere dan dasar perairan. Daerah permukaan pada kedalaman 0-1 m kaya akan noise atau gangguan yang menyebabkan nilai pada daerah ini memiliki nilai hambur balik hampir sama dengan target. Gangguan tersebut diakibatkan oleh dua jenis ganguan ambient noise yaitu gangguan dari lingkungan dan gangguan dari alat itu sendiri dikenal dengan istilah self noise (Urick, 1983). Gangguan dari lingkungan terjadi karena pada daerah tersebut adanya reverberasi suara dipermukaan air akibat dasar perairan yang terlalu keras, yang menyebabkan suara memantul kembali ke permukaan dan dibagian permukaan terdapat tegangan permukaan air sebagai dinding yang memantulkan kembali lagi ke kolom perairan. Peristiwa ini akan terus berlangsung hingga intensitas dari suara tersebut melemah atau sampai suara tersebut mengalami penetrasi energinya stabil.

Pada kedalaman 1,63 m terdeteksi objek bola sphere sebesar -39,9 dB yang digambarkan dengan warna biru dan inset tabel pada gambar yang menunjukan nilai pada titik tersebut. Pada pengukuran ini kondisi lingkungan yaitu, suhu perairan $26,7^{\circ} \mathrm{C}, \mathrm{pH}$ terukur 5,6 , salinitas $0 \%$ dengan kecepatan suara hasil perhitungan algoritma Leroy (1969) sebesar 1500,96 m/s. Hasil pengukuran terlihat bahwa nilai hambur balik target yang dihasilkan dari algoritma memiliki nilai yang sama dengan nilai kontrol (bola sphere) yaitu sebesar $-39,9$ dB dengan kecepatan suara sebesar 1500 $\mathrm{m} / \mathrm{s}$ (Biosonic, 2004). Durasi pulsa yang digunakan sama dengan standar baku yang telah ditentukan dari pabrikan yaitu sebesar 0,5 ms. Penggunaan durasi pulsa yang sama merupakan syarat yang harus dipenuhi dalam uji kalibrasi dengan menggunakan nilai kontrol bola sphere, karena berkaitan dengan resolusi nilai hamburbalik suara yang dihasilkan (Biosonic, 2004).

Nilai hambur balik dari dasar perairan sebesar $-18 \mathrm{~dB}$ pada kedalaman 2,45 m yang digambarkan dengan warna coklat. Kuatnya nilai hambur balik ini karena dasar perairan tersebut merupakan dasar yang tersusun dari bahan keramik yang memiliki tekstur yang keras dan padat sehingga suara akan memantul dengan mudah jika mengenainya. Gambar 2 (c) merupakan gambar echo envelope dari proses nilai hambur balik suara yang dihasilkan. Terbentuk tiga gundukan utama yang menggambarkan nilai hambur balik masingmasing objek dimana objek tersebut adalah daerah near field, Lurton (2002) menyatakan bahwa near field daerah dimana terjadi reverberasi yang sangat tinggi baik karena adanya tegangan permukaan air ataupun dari karakteristik instrumen tersebut dalam melakukan penetrasi suara kedalam perairan, umumnya pada daerah permukaan. Gundukan kedua adalah nilai hambur balik dari target kontrol (bola sphere) dan gundukan yang terakhir adalah nilai hambur balik dari dasar perairan. Tabel 1 statistik hasil kuantifikasi algoritma hasil pengukuran.

Tabel 1. Deskripsi statistik data hasil pengukuran

\begin{tabular}{lr}
\hline \multicolumn{2}{c}{ Hasil pengukuran } \\
\hline $\mathrm{N} \mathrm{Valid} \quad$ Missing & 1654 \\
Mean & 0 \\
Median & -39.9611 \\
Std. Deviation & -39.9038 \\
Variance & .13268 \\
Skewness & .018 \\
Std. Error of Skewness & -.116 \\
Kurtosis & .060 \\
Std. Error of Kurtosis & -.226 \\
Minimum & .120 \\
Maximum & -40.20 \\
\hline
\end{tabular}


Data hasil pengukuran yang digunakan sebagai data pembentukan algoritma yaitu sebanyak 1654 data. Hasil kuantifikasi algoritma terhadap data hasil pengukuran diperoleh bahwa nilai rata-rata yang diperoleh yaitu sebesar 39,96 dB dengan rata-rata error yaitu 0,06 terhadap nilai kontrol (bola sphere) sebesar $-39,90 \mathrm{~dB}$. Nilai maksimum yang terukur yaitu sebesar $-40,20 \mathrm{~dB}$ dan nilai minimum yang terukur $-39,69 \mathrm{~dB}$. Ukuran penyebaran data dari nilai rataratanya atau dikenal dengan istilah simpangan baku yaitu sebesar 0,13 dB. Nilai varian adalah nilai kuadrat dari nilai simpangan baku yang diperoleh dengan nilai sebesar 0,018 , merupakan nilai variasi yang rendah. Nilai tersebut dapat dikatakan bahwa nilai hasil pengukuran tidak begitu menyimpang jauh dari nilai sebenarnya dan memiliki kemungkinan tingkat homogenitas yang cukup tinggi. Berikut gambar distribusi data hasil pengukuran Tabel 2 dan Gambar 3.

Dapat dilihat bahwa kemunculan nilai $-39,90 \mathrm{~dB}$ hasil perhitungan algoritma memiliki frekuensi kemunculan paling besar dengan jumlah kemunculan sebanyak 791 data terhadap total data sebanyak 1654 data. Jika dinyatakan dalam bentuk persentase nilai ini memiliki persentase sebesar $47,8 \%$. Sisa dari data yang diperoleh menyebar menujukan dibeberapa nilai antara lain nilai maksimum yang diperoleh -39,69 $\mathrm{dB}$ dan nilai minimum sebesar $-40,20$ dB. Secara deskriptif statistik dapat dilihat bahwa nilai kemunculan paling banyak bernilai $-39,90 \mathrm{~dB}$, yaitu nilai yang sama dengan spesifikasi dari bola sphere yang digunakan.

Tabel 2. Distribusi persentase data hasil pengukuran

\begin{tabular}{lrrrrr}
\hline & Frequency & Percent & $\begin{array}{c}\text { Valid } \\
\text { Percent }\end{array}$ & $\begin{array}{c}\text { Cumulative } \\
\text { Percent }\end{array}$ \\
\hline Valid & -40.20 & 73 & 4.4 & 4.4 & 4.4 \\
& -40.13 & 457 & 27.6 & 27.6 & 32.0 \\
& -40.05 & 2 & .1 & .1 & 32.2 \\
& -39.98 & 50 & 3.0 & 3.0 & 35.2 \\
& -39.90 & 791 & 47.8 & 47.8 & 83.0 \\
& -39.83 & 181 & 10.9 & 10.9 & 94.0 \\
& -39.76 & 18 & 1.1 & 1.1 & 95.0 \\
& -39.69 & 82 & 5.0 & 5.0 & 100.0 \\
Total & 1654 & 100.0 & 100.0 & \\
\hline
\end{tabular}

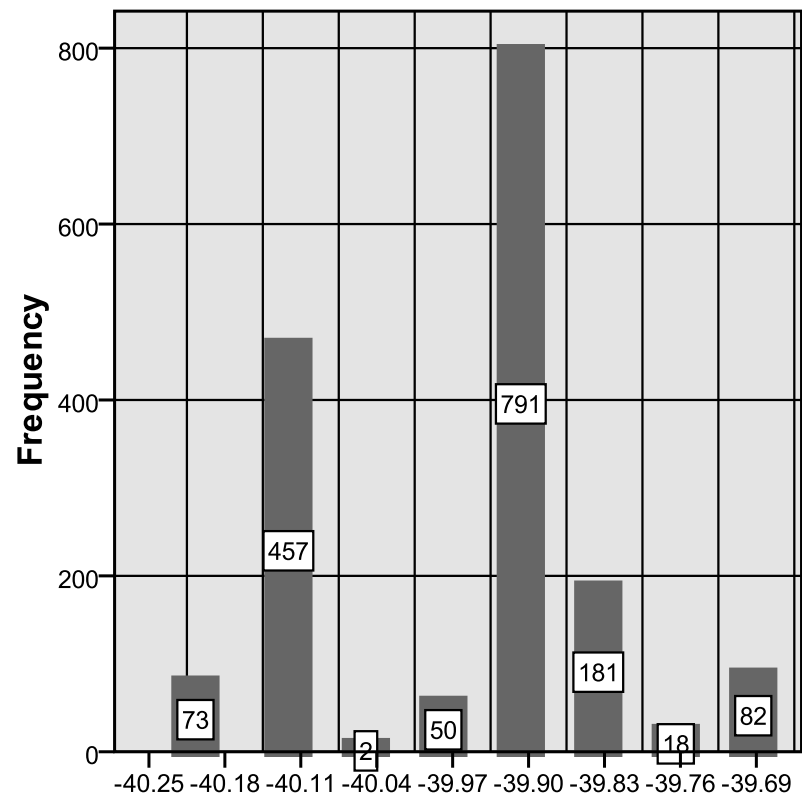

Mean $=-3$ Std. Dev. $=1$

Hasil pengukuran

Gambar 3. Distribusi frekuensi data hasil pengukuran 
Dilakukan pengujian statistik untuk melihat apakah data yang diperoleh hasil algoritma tersebut memiliki nilai yang hampir sama atau menyebar berbeda dengan menggunakan uji homogenitas Fisher (Uji-F). Syarat untuk melakukan uji homogenitas Fisher (Uji-F) adalah sebaran data terdistribusi normal. Data hasil pengukuran yang diperoleh memenuhi kaidah sebaran normal dimana ratio antara skewness/std.Error of Skewnessdan kurtosis/std.Error of Kurtosisyaitu berkisar antara $-2 \mathrm{~s} / \mathrm{d}+2$ dari hasil perhitungan diperoleh 0,19 dan 1,88 (Tabel 1) dengan nilai tersebut dapat dikatakan bahwa data tersebut menyebar normal. Hasil dari uji Fisher ditunjukan pada Tabel 3.

Dalam pengujian statistik semua data yang diperoleh dari hasil kuantifikasi algoritma dikonversi kedalam bentuk nonlinier yang kemudian data tersebut diuji dengan hipotesis, $\mathrm{H}_{0}$ adalah nilai varian dari kelompok data hasil pengukuran sama dengan nilai varian dari kelompok data kontrol atau dapat dikatakan nilai yang dihasilkan homogen. $\mathrm{H}_{1}$ adalah nilai varian dari kelompok data hasil pengukuran tidak sama dengan nilai varian dari kelompok data kontrol. Dapat dikatakan nilai yang dihasilkan tidak homogen. Sedangkan untuk kriteria pengujian hipotesis diterima $\mathrm{H}_{0}$, jika $\mathrm{F}_{\text {hitung }}<\mathrm{F}_{\text {tabel }}$ dan ditolak $\mathrm{H}_{0}$, jika $\mathrm{F}_{\text {hitung }}>\mathrm{F}_{\text {tabel. }}$. Banyaknya data yang digunakan untuk uji homogenitas yaitu sebanyak 1654 data. Pada bagian ini nilai hambur balik Target strength dari bola sphere diinisialisasi nilai sebesar -39,9 dB sesuai dengan spesifikasi dari bola tersebut, sehingga dapat dikatakan nilai dari bola sphere adalah homogen.

Hasil uji homogenitas diperoleh nilai $F_{\text {hitung }}$ sebesar 0,312 dan $F_{\text {tabel }}$ sebesar 1,11, maka $F_{\text {hitung }}<F_{\text {tabel }}$ berarti $H_{0}$ diterima yaitu nilai varian dari data hasil pengukuran sama dengan nilai varian dari data kontrol dalam hal ini bola sphere atau dapat dikatakan nilai yang dihasilkan homogen.

\subsection{Hasil Uji Akurasi dan Presisi}

Dalam pengujian suatu alat ukur apakah alat tersebut dapat menunjukan nilai atau besaran dari suatu objek diperlukan suatu pengujian yang menggambarkan nilai dan besaran objek tersebut. Nilai suatu objek akan tergambar sebenarnya apabila alat tersebut memiliki akurasi dan presisi yang baik. Akurasi adalah tingkat kedekatan atau kosistensi pengukuran terhadap nilai yang benar (true value), sedangkan presisi adalah tingkat kedekatan pengukuran terhadap nilai rerata (Soeta'at, 1996). Presisi dikatakan baik jika jumlah kuadrat dari pengukuran lebih kecil atau sama dengan dari dua kali jumlah kuadrat nilai kontrol, sedangkan akurasi dikatakan baik apabila jumlah kuadrat selisih pengukuran dengan nilai kontrol lebih kecil atau sama dengan dari tiga kali jumlah kuadrat nilai kontol. Berikut adalah hasil perhitungan untuk uji akurasi dan presisi. Berikut Tabel 4. adalah hasil perhitungan untuk uji akurasi dan presisi.

Dapat dilihat bahwa jumlah kuadrat dari pengukuran (hasil algoritma) yaitu sebesar -47,73 dB lebih kecil dari dua kali jumlah kuadrat kontrol yaitu sebesar -44,60 dB, sehingga dapat dikatakan bahwa alat ini memiliki presisi yang baik.

Akurasi dari alat ini menunjukan akurasi yang baik dimana jumlah selisih kuadrat antara hasil pengukuran dan nilai kontrol yaitu sebesar $-77,26 \mathrm{~dB}$ lebih kecil dari tiga kali jumlah kuadrat nilai kontrol yaitu sebesar $-42,84 \mathrm{~dB}$, dengan adanya pengujian ini dapat disimpulkan bahwa alat dan penerapan algoritma yang digunakan memiliki tingkat akurasi dan presisi yang baik untuk pengukuran.

\subsection{Rancang Bangun Pengolahan}

Hasil akusisi dari Cruzpro fishfinder merupakan nilai dalam bila-ngan digital number 8 bit yang berbentuk ASCII (American Standard Code for Information Interchange). Bilangan 8 bit ini dimulai dari 0 hingga maksimum yang dapat dipantulkan sebesar 255 . Secara umum bentuk data ini dapat diakses oleh bahasa pemrograman $\mathrm{C}++$, seperti Matlab dan Fortran. Matlab berkerja dalam bentuk matrik-matrik data, sehingga data hasil akusisi harus diubah dalam bentuk matrik-matrik data. Data hasil akusisi instrumen diubah dalam bentuk matrik CSV (Comma Separated Values) dengan fungsi konversi pada Matlab.

Pembuatan dalam Matlab dapat dibuat dalam bentuk Package Matlab yaitu serangkaian algoritma yang terdiri 
dari beberapa sub-sub algoritma yang saling terkait satu sama lainnya. Gambar 4 adalah bagian dari tampilan software pengolahan.

Ditunjukan pada Gambar 4 bagian (a) merupakan tampilan pertama saat program dijalankan, dimana pada halaman ini user diminta memasukan data mentahan dalam bentuk string data ('xxxxx.xxx'). Bagian ini merupakan awal proses untuk pemisahan data pada tahapan berikutnya. Gambar 4 (b) adalah bagian untuk memasukan parameterparameter alat seperti frekuensi yang digunakan dalam bentuk $(\mathrm{Hz})$, durasi pulsa (ms) dan diameter transduser (m) yang digunakan. Karena ketiga parameter ini yang akan menentukan daya jangkau signal di dalam kolom perairan. Gambar 4 (c) terdiri dari dua macam masukan yang pertama dalam bentuk masukan dan yang kedua dalam bentuk pilihan. Masukan pada bagian ini merupakan masukan parameter lingkungan yaitu suhu, salinitas dan PH. Nilai-nilai tersebut dimasukan dalam bentuk angka.

Sofware yang dikembangkan untuk pengolahan data singelbeam mengikuti kepada tiga bagian utama dalam sebuah software pengolahan dimana untuk bagian masukan pada ini terdiri dari beberapa inputan dan beberapa bagian inputan pilihan. Proses pengolahan data singelbeam Cruzpro fishfinder dalam bentuk pengolahan pada Gambar 5 . menggambarkan proses pengolahan data dari mulai pemanggilan data, pemisahan data dari bilangan digital number menjadi matrik-matrik data, proses filtrasi, pemasukan beberapa parameterparameter yang terkait baik dari lingkungan dan alat itu sendiri, proses pengkuantifikasian dengan algoritma yang diciptakan hingga proses visualisasi.

Tabel 3 . Uji homogenitas Fisher

\begin{tabular}{lrr}
\hline & Hasil Pengukuran & Bola sphere \\
\hline n-sampel & 1654 & 1654 \\
Jumlah & 0,167018556 & 0,169252661 \\
Rata-Rata & 0,000100979 & 0,000102329 \\
Varian & $2,82857 \mathrm{E}-36$ & $5,0643 \mathrm{E}-36$ \\
F-hit & 0,311957006 & \\
F-tabel & 1,11 & \\
\hline
\end{tabular}

Tabel 4. Hasil uji akurasi dan presisi terhadap bola sphere

\begin{tabular}{|c|c|c|c|}
\hline & Notasi & Non_Linier & Desibel(dB) \\
\hline \multirow{2}{*}{ Presisi } & $\begin{array}{r}\Sigma k n t r l^{2} \\
2 \times \Sigma k n t r l^{2}\end{array}$ & $\begin{array}{l}1.7320 \mathrm{E}-05 \\
3.4639 \mathrm{E}-05\end{array}$ & $\begin{array}{l}-47.61 \\
-44.60\end{array}$ \\
\hline & Spngkrn ${ }^{2}$ & $1.6870 \mathrm{E}-05$ & -47.73 \\
\hline \multirow[t]{2}{*}{ Akurasi } & $3 \times \Sigma k n t r l^{2}$ & 5.1959E-05 & -42.84 \\
\hline & Eselisih ${ }^{2}$ & $1.8778 \mathrm{E}-08$ & -77.26 \\
\hline
\end{tabular}




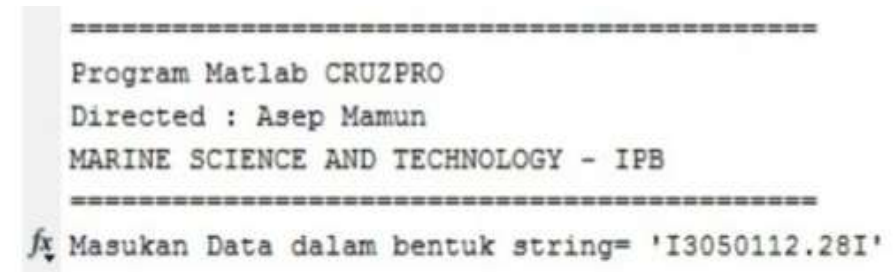

(a)

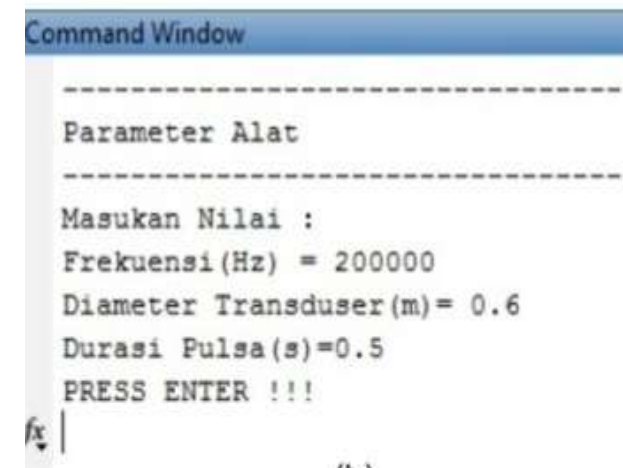

(b)

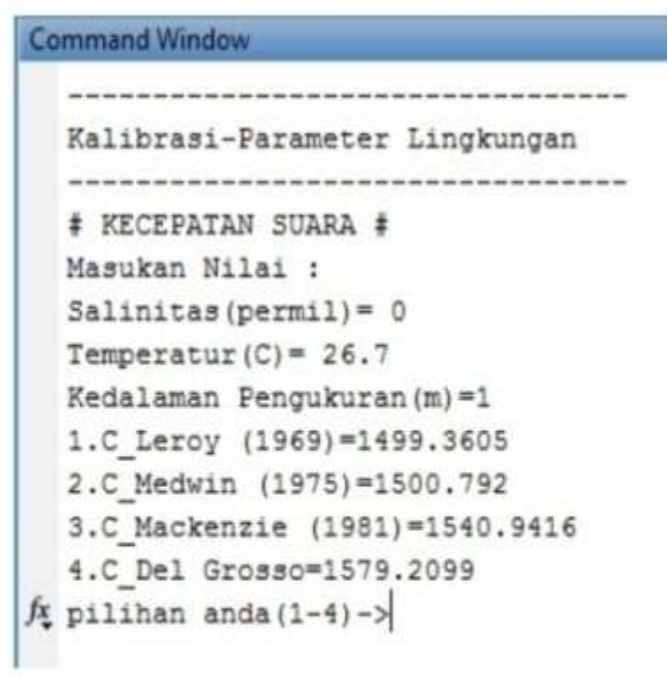

(c)

Gambar 4. (a) Tampilan package input di Matlab, (b) input parameter alat, (c) input parameter lingkungan dan pemilihan nilai kecepatan suara

\section{KESIMPULAN}

Telah terbentuknya suatu algoritma nilai hambur balik hidroakustik berupa nilai Target strength dan Scattering volume. Dari hasil uji coba yang dilakukan terhadap bola sphere (bola yang memiliki nilai hambur balik pasti yaitu sebesar $-39,9 \mathrm{~dB}$ ) diperoleh bahwa penyimpangan terhadap nilai rata-ratanya yaitu sebesar 0,13 dengan selang kepercayaan $95 \%$, merupakan nilai penyimpangan yang relatif kecil. Dari hasil uji statistik diperoleh nilai varian dari data hasil pengukuran sama dengan nilai varian dari data kontrol atau dapat dikatakan nilai yang dihasilkan homo- gen. Dari hasil uji akurasi dan presisi diperoleh bahwa algoritma yang dihasilkan memiliki tingkat akurasi dan presisi yang baik, oleh karena itu alat dan algoritma yang dihasilkan dapat diaplikasikan untuk pengkajian suatu objek dari nilai hambur balik akustik yang dihasilkan. Software yang dikembangkan untuk pengolahan data singlebeam mengikuti kepada tiga bagian utama dalam sebuah pengolahan yaitu bagian masukan, bagian pengolahan dan bagian visualisasi. Dimana untuk bagian masukan pada ini terdiri dari beberapa inputan isian dan beberapa bagian inputan pilihan. 


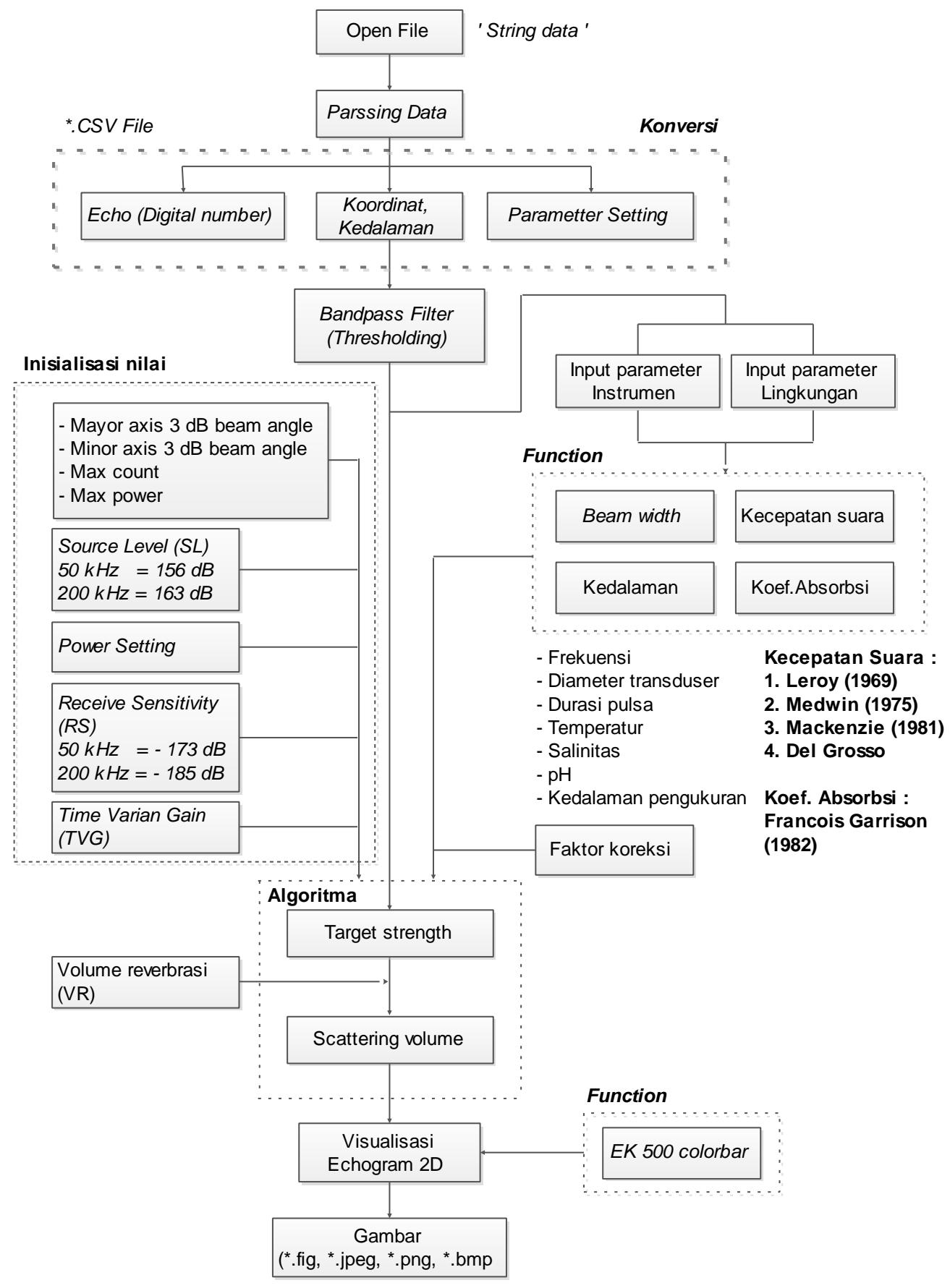

Gambar 5. Diagram alir proses pembentukan algoritma nilai hambur akustik suatu objek dalam bentuk Target Strength (TS) dan Scattering volume (Sv)

\section{DAFTAR PUSTAKA}

Biosonics. 2004. User Guide Visual: Analyzer 4. Seattle: Biosonic Inc.

Desamparados, Mand Torres Mediana. 2010. Theoretical and Experimental Studies of Seafloor Backscatter. Centre for marine Science and Technology, Curtin University of Technology, Perth, Australia.
Greenlaw,C.F., D.V.Holliday, D.E. Mc Gehee.2004. High Frequency Scattering From Saturated Sand Sediments. Journal. Acoustics Society of America.,115: 2818-2823.

Johanesson, K.A. and Mitson, R.B. 1983. Fisheries Acoustic. A Practical Manual for Acoustic Biomass Estimation. FAO Fisheries Tech. 
Kadir, A. 2013. Pengenalan algoritma pendekatan secara visual dan interaktif menggunakan Raptor. Penerbit Andi. Yogyakarta.

Leroy, C.C. 1969. Development of Simple Equation for Accurate and more Realistic Calculation of The Speed of Sound in Sea Water. Journal. Acoustics Society of America, 46:216-226.

Lurton, X. 2002. An Introduction to Underwater Acoustics: Principles and Applications. Praxis Publishing. Chichester.

Simmonds, E.J. and D.N.MacLennan. 2005. Fisheries Acoustic: Theory and Practice $2^{\text {nd }}$ ed. Blackwell Science Ltd.

Soeta'at.1996. Hitung kuadrat terkecil lanjut, Jurusan Teknik Geodesi dan Geomatika. Fakultas Teknik. Universitas Gajah Mada. Yogyakarta.

Supardi, U.S. 2011. Aplikasi statistika dalam penelitian. Ufuk Press. Jakarta.

Tanudjaja, H.2007. Pengolahan sinyal digital dan sistem pemerosesan sinyal. Penerbit Andi. Yogyakarta.

Urick, J.1983. Principle of Underwater Acoustic. Mc Graw Hill. New York. 